\title{
B-cell specific Moloney leukemia virus insert site 1 and peptidyl arginine deiminase IV positively regulate carcinogenesis and progression of esophageal squamous cell carcinoma
}

\author{
WEI WANG ${ }^{1 *}$, HUAI-JUN JI ${ }^{2 *}$, NING-BO SUN ${ }^{3}$, XIAO-TIAN CHANG ${ }^{4}$, BING XU $^{4}$, \\ YAO WANG $^{4}$, MING CAO ${ }^{1}$, QIANG ZHU ${ }^{1}$, QI ZANG ${ }^{1}$ and ZHONG-MIN JIANG ${ }^{1}$ \\ ${ }^{1}$ Department of Thoracic Surgery, Qianfoshan Hospital Affiliated to Shandong University, Jinan, Shandong 250014; \\ ${ }^{2}$ Division of Surgery, Graduate Department, Weifang Medical College, Weifang, Shandong 261031; ${ }^{3}$ Department of \\ Thoracic Surgery, Shengli Oilfield Central Hospital, Dongying, Shandong 257034; ${ }^{4}$ Medical Research \\ Center of Shandong Provincial Qianfoshan Hospital, Jinan, Shandong 250014, P.R. China
}

Received February 17, 2016; Accepted February 13, 2017

DOI: $10.3892 / 01.2017 .6001$

\begin{abstract}
High expression of B-cell specific Moloney leukemia virus insert site 1 (Bmi-1) and peptidyl arginine deiminase IV (PADI4) is associated with esophageal carcinoma. However, few studies have investigated the association between the Bmi-1 and PADI4 genes. The aim of the present study was to evaluate the expression of Bmi-1 and PADI4 and identify the association between the Bmi-1 and PADI4 genes in esophageal squamous cell carcinoma (ESCC) tissues. Bmi-1 and PADI4 gene expression levels were measured using immunohistochemistry, western blotting and reverse transcription-quantitative polymerase chain reaction in ESCC tissues from 86 patients who had not received pre-operative chemoradiation. The results revealed that the Bmi-1 and PADI4 genes had increased expression in carcinoma tissues compared with pericarcinous tissue $(\mathrm{P}<0.05)$. Bmi-1 gene expression was revealed to be associated with differentiation degree, clinical stage and lymph node metastasis $(\mathrm{P}<0.05)$, but had no association with gender, age or depth of invasion $(\mathrm{P}>0.05)$. The expression of PADI4 was associated with clinical stage, depth of invasion and lymph node metastasis $(\mathrm{P}<0.05)$, but was not associated with gender, age or differentiation degree $(\mathrm{P}>0.05)$. In addition, there was a positive association between Bmi-1 and PADI4 gene expression in ESCC $(\mathrm{P}<0.05)$. These
\end{abstract}

Correspondence to: Professor Zhong-Min Jiang, Department of Thoracic Surgery, Qianfoshan Hospital Affiliated to Shandong University, 16766 Jingshi Road, Jinan, Shandong 250014, P.R. China E-mail: qyjzm@sina.cn

*Contributed equally

Key words: esophageal squamous cell carcinoma, polycomb group protein, B-cell specific Moloney leukemia virus insert site 1, peptidyl arginine deiminase IV, immunohistochemistry, western blot analysis, reverse transcription-quantitative polymerase chain reaction, $\mathrm{p} 53$ results indicated that Bmi-1 and PADI4 positively regulate carcinogenesis and progression of ESCC.

\section{Introduction}

Esophageal cancer is the eighth most common type of cancer in the world, making it a serious threat to human health (1). There are 240,000 new esophageal cancer cases in China every year (2). Esophageal squamous cell carcinoma (ESCC) is the major histological type of esophageal cancer. ESCC is a highly aggressive malignancy due to late diagnosis, rapid progression and poor prognosis of survival. Therefore, the mortality rate of esophageal cancer is similar to the incidence of esophageal cancer $(3,4)$. There have been numerous improvements in surgery, radiotherapy and chemotherapy; however, the 5 -year overall survival rate remains poor due to diagnosis of the disease at an advanced stage (5). It is important for ideal markers to be identified as these may help in early diagnosis of the disease.

The B-cell specific Moloney leukemia virus insert site 1 (Bmi-1) gene, a member of the polycomb group of proteins, was identified in 1999 and originally isolated as an oncogene in the generation of mouse pre-B-cell lymphomas (6). As a transcriptional repressor through chromatin modification, Bmi-1 is involved in axial patterning, cell cycle regulation, hematopoiesis and senescence $(7,8)$. Overexpression of Bmi-1 has been observed in a variety of human cancers, including gastric (9), breast (10), colorectal (11) and head and neck cancers (12), and it was also observed that expression of Bmi-1 is associated with the development of tumors $(13,14)$. It was reported that overexpression of Bmi-1 in primary human cancer cells may cause downregulation of the INK4a-ARF locus and affect the pathway of p14ARF-Mdm2-p53 (15). It has been hypothesized that Bmi-1 is an important inhibitor of the p53 pathway $(13,15)$.

Peptidyl arginine deiminase IV (PADI4 or PAD4) is a post-translational modification enzyme that converts arginine residues at histone tails to citrulline, in the presence of $\mathrm{Ca}^{2+}(16)$. The expression of PADI4 has been detected in 
human $\mathrm{CD} 34^{+}$stem/progenitor cells (17), and it is involved in the regulation of hematopoietic progenitor proliferation (18). Our previous study detected the overexpression of PADI4 in various malignancies, including lung adenocarcinoma, hepatocellular cancer, breast cancer and metastatic cancer (19). Tanikawa et al reported that citrullination of H4R3 by PADI4 is associated with the p53 pathway (20).

In the present study, the expression levels and clinical significance of Bmi-1 and PADI4 were investigated in esophageal cancer tissues and pericarcinous tissues in order to observe differences in the expression of Bmi-1 and PADI4.

\section{Materials and methods}

ESCC patient sample preparation. The samples of esophageal cancer tissues and adjacent noncancerous mucosal tissues were obtained from 26 patients who had received surgical treatment between January 2014 and December 2015 in the Department of Chest Surgery, Qianfoshan Hospital of Shandong University (Shandong, China). Normal tissues located $5 \mathrm{~cm}$ away from the tumor edge were collected during surgery. Tissue microarrays containing 120 esophageal tissue sections were commercially obtained from Chaoying Bioscience (Shanxi, China). The slides contained ESCC tissues $(n=60)$ and adjacent normal tissues. Section thickness was $\sim 5 \mu \mathrm{m}$. Firstly, the sections were stained with hematoxylin and eosin (Boster, Co., Ltd., Beijing, China) within each tissue core. All patients had not received radiotherapy or chemotherapy prior to surgery. Postoperative pathologic results of the esophageal cancer biopsies showed they were all squamous cell carcinomas. Patient information, including gender, age and clinicopathological characteristics, was obtained from the medical records or the manufacturer. The enrolled patients included 61 males and 25 females, and the median age was 58 years (range, 36-76). According to the World Health Organization standard pathology classification, the tumors of 9 patients $(10.5 \%)$ were diagnosed as well-differentiated tumors, the tumors of 47 patients $(54.7 \%)$ were diagnosed as moderately differentiated tumors, and the tumors of 30 patients (34.9\%) were diagnosed as poorly differentiated tumors. In these cases, 70 patients had no lymph node metastasis and 16 patients had lymph node metastasis. All patients provided informed consent prior to specimen acquisition and the present study was approved by the Research Ethics Committee of the Qianfoshan Hospital Affiliated to Shandong University.

Immunohistochemical staining. Tissue samples were soaked in $10 \%$ neutral buffered formalin, embedded in conventional paraffin, and the section thickness was $\sim 3 \mu \mathrm{m}$. Following deparaffinization, the specimens were hydrated and incubated with an epitope retrieval solution (Boster, Co., Ltd.; pH 6.0) in a microwave (temperature controlled at $95-100^{\circ} \mathrm{C}$ ) for $20 \mathrm{~min}$. The slices were then cooled to room temperature and incubated with $0.3 \% \mathrm{H}_{2} \mathrm{O}_{2}$ for $10 \mathrm{~min}$ at room temperature to inactivate endogenous peroxidase, and then rinsed with PBS. The specimens were then incubated with rabbit polyclonal antibody for Bmi-1 (cat. no., ab85688; dilution, 1:500; Abcam, Cambridge, UK) and mouse monoclonal antibody for PADI4 (cat. no., ab128086; dilution, 1:500; Abcam) at $4^{\circ} \mathrm{C}$ overnight. Specimens were then incubated with ready-to-use secondary antibody EliVision $^{\text {TM }}$ plus kit (cat. no., KIT-9901; Maixin-Bio; Lab Vision, Kalamazoo, USA), according to the manufacturer's protocol. The specimens were then washed using PBS, and diaminobenzidine (Dako; Agilent Technologies, Inc., Santa Clara, CA, USA) chromogenic reagent was added. Termination of the chromogenic reaction was achieved with water. Following counterstaining with hematoxylin, specimens were dehydrated, mounted and observed under a Nikon 50i fluorescence microscope, magnification, x200 (Nikon Corporation, Tokyo, Japan).

Interpretation of the results. The immunohistochemical specimens were evaluated by German semi-quantitative statistical methods. Briefly, slices were observed under an optical microscope (magnification, x200) and evaluated using positive staining intensity and percentage of positive staining by two pathologists. Positive staining intensity was rated as follows: 0, No staining; 1, light yellow; 2, yellow; 3, dark yellow. The extent of stained cells was ranked as follows: $0,0-5 \%$; $1,5-25 \% ; 2,25-50 \% ; 3,50-75 \% ; 4,75-100 \%$. The final score was determined by multiplying the staining intensity scores with the extent of positivity scores of cells: 0-2, negative (-); 3-5, weak (+); 6-8, moderate (++); and 9-12, strong (+++) (21).

Western blot analysis. Human esophageal cancer tissues were homogenized and centrifuged at $12,000 \mathrm{x} g$ for $30 \mathrm{~min}$ at $4^{\circ} \mathrm{C}$. The protein concentrations were determined using the bicinchoninic acid protein assay kit (Boster Biological Technology, Pleasanton, CA, USA). Total protein (30 $\mu \mathrm{g})$ was separated by $10 \%$ SDS-PAGE, transferred to a polyvinylidene fluoride membrane and blocked in 5\% milk. The membranes were incubated with rabbit polyclonal antibody for Bmi-1 (cat. no., ab85688, dilution, 1:8,000; Abcam) and mouse monoclonal antibody for PADI4 (cat. no., ab128086, dilution; 1:2,000; Abcam) or mouse antibody for GAPDH (cat. no., AF0006; dilution, 1:6,000; Beyotime Institute of Biotechnology, Haimen, China) at $4^{\circ} \mathrm{C}$ overnight. The Goat anti-Mouse secondary antibody (cat. no., A0258; dilution, 1:8,000; Beyotime Institute of Biotechnology) and Goat anti-Rabbit secondary antibody (cat. no., A0239; dilution, 1:8,000; Beyotime Institute of Biotechnology) was incubated with the membrane for $1 \mathrm{~h}$ at room temperature in TBS with Tween-20. Finally, the immunoreactive protein bands were visualized with Immobilon ${ }^{\mathrm{TM}}$ Western Chemiluminescent HRP Substrate (EMD Millipore, Billerica, MA, USA).

Reverse transcription-quantitative polymerase chain reaction $(R T-q P C R)$. Total RNA was extracted from frozen specimens using the E.Z.N.A. ${ }^{\circledR}$ total RNA kit II (Omega Bio-Tek, Inc., Norcross, GA, USA), according to the manufacturer's protocol. Total RNA $(1 \mu \mathrm{g})$ was then used to perform reverse transcription for first-strand cDNA using the revert aid first strand cDNA synthesis kit (Thermo Fisher Scientific, Inc., Waltham, MA, USA). Subsequently, qPCR was performed in triplicate on the ABI VIIA7 real-time PCR system (Applied Biosystems; Thermo Fisher Scientific, Inc.) with SuperReal PreMix Plus (SYBR-Green; Tiangen Biotech Co., Ltd., Beijing, China) with primers that amplified a specific single product by melt curve. Primer sequences for Bmi-1, PADI4 and $\beta$-actin were as follows: Bmi-1 forward, 5'-CCACCTGATGTGTGTGCT 
Table I. Bmi-1 protein expression in esophageal cancer and normal esophageal tissues.

\begin{tabular}{lccccc}
\hline & & \multicolumn{4}{c}{ Bmi-1 expression } \\
\cline { 3 - 5 } Pathological characteristic & Total cases, $\mathrm{n}$ & Positive, $\mathrm{n}$ & Negative, $\mathrm{n}$ & Positive rate, $\%$ & $\chi^{2}$ \\
\hline Cancerous tissue & 86 & 63 & 23 & 73.3 & 31.876 \\
Normal tissue & 86 & 26 & 60 & 30.2 & \\
\hline
\end{tabular}

Bmi-1, B-cell-specific Moloney leukemia virus insert site 1.

Table II. PADI4 protein expression in esophageal cancer and normal esophageal tissues.

\begin{tabular}{|c|c|c|c|c|c|c|}
\hline \multirow[b]{2}{*}{ Pathological characteristic } & \multirow[b]{2}{*}{ Total cases, $\mathrm{n}$} & \multicolumn{3}{|c|}{ PADI4 expression } & \multirow[b]{2}{*}{$\chi^{2}$} & \multirow[b]{2}{*}{ P-value } \\
\hline & & Positive, $\mathrm{n}$ & Negative, $\mathrm{n}$ & Positive rate, $\%$ & & \\
\hline Cancerous tissue & 86 & 59 & 26 & 68.6 & 17.011 & $\mathrm{P}<0.05$ \\
\hline Normal tissue & 86 & 32 & 54 & 37.2 & & \\
\hline
\end{tabular}

PAI4, peptidyl arginine deiminase IV.

TTG-3' and reverse, 5'-TTCAGTAGTGGTCTGGTCTTGT-3'; PADI4 forward, 5'-GGGGTGGTCGTGGATATTGC-3' and reverse, 5'-CCCGGTGAGGTAGAGTAGAGC-3'; and $\beta$-actin forward, 5'-GACCACACCTTCTACAATGAG-3' and reverse, 5'-GCATACCCCTCGTAGATGGG-3'.

All reactions were done in a $20 \mu \mathrm{l}$ reaction volume. Subsequent to pre-denaturing, PCR was performed at $95^{\circ} \mathrm{C}$ for $15 \mathrm{~min}$, followed by 40 cycles at $95^{\circ} \mathrm{C}$ for $10 \mathrm{sec}$ and $62^{\circ} \mathrm{C}$ for $32 \mathrm{sec}$. Gene expression was analyzed with the comparative threshold cycle $(\mathrm{Cq})$ method following normalization to the reference gene $\beta$-actin. $\Delta \Delta \mathrm{Cq}$ was used to calculate the relative amount of the transcripts in the esophageal cancer samples and the control group, which were normalized to the endogenous control (22). $\Delta \Delta \mathrm{Cq}=\Delta \mathrm{Cq}$ (esophageal cancer) $-\Delta \mathrm{Cq}$ (control) for RNA samples. The fold change for each esophageal cancer sample relative to the control sample $=2^{-\Delta \Delta \mathrm{Cq}}$. When the expression showed a 2-fold decrease or increase compared with normal counterpart tissue, it was considered as an altered expression.

Statistical analysis. The correlation between Bmi-1 and PADI4 mRNA expression levels was analyzed by Pearson's coefficient test. The experimental data of protein expression was statistically analyzed with $\chi^{2}$ test and Fisher's exact test. All statistical analyses were performed using the SPSS 21.0 software package (IBM SPSS, Armonk, NY, USA). P<0.05 was considered to indicate a statistically significant difference.

\section{Results}

Immunodetection of Bmi-1 and PADI4 in ESCC tissues. The expression rates of Bmi-1 in ESCC tissue and normal mucosa were 73.3 and $30.2 \%$, respectively. The expression rates of PADI4 in ESCC tissue and normal mucosa were 68.6 and $37.2 \%$, respectively. The differences in the expression of Bmi-1 and PADI4 were statistically significant between esophageal cancer tissue and normal esophageal mucosa $(\mathrm{P}<0.05$; Tables I and II). Bmi-1 and PADI4 were expressed in the nucleus of tumor cells based on immunohistochemical staining of tumors. The staining of Bmi-1 and PADI4 are shown at the original magnification of x200 (Fig. 1).

Association between the expression of Bmi-1 and PADI4 with clinical pathological parameters. The importance of Bmi-1 and PADI4 in ESCC was evaluated by correlating its expression level with clinicopathological features. Several of the analyzed clinicopathological features exhibited significant associations with the expression levels (Table III). The results revealed that the expression of Bmi-1 was associated with differentiation degree, clinical stage and lymph node metastasis $(\mathrm{P}<0.05)$, but not with patient gender, age and depth of invasion $(\mathrm{P}>0.05)$. The expression of PADI4 was associated with clinical stage, depth of invasion and lymph node metastasis $(\mathrm{P}<0.05)$, but not with patient gender, age and differentiation degree $(\mathrm{P}>0.05)$.

Quantifying Bmi-1 and PADI4 expression levels by western blot analysis and RT-qPCR. Bmi-1 and PADI4 protein levels were quantified by western blot analysis. The protein was detected in ESCC and corresponding para-carcinoma tissues. Compared with para-carcinoma tissues, the expression levels of Bmi-1 and PADI4 were significantly increased in ESCC, with statistically significant differences $(\mathrm{P}=0.014$ and 0.021 , respectively; Fig. 2). Transcription of Bmi-1 and PADI4 was quantified by RT-qPCR. The results revealed that Bmi-1 mRNA was overexpressed in 17 of $26(65.38 \%)$ esophageal tumor tissues ( $>2$-fold), and PADI4 mRNA was overexpressed in 14 of 26 (53.85\%; >2-fold). As shown in Fig. 3 and Table IV, the ESCC tissues exhibited an increased level of Bmi-1 and PADI4 mRNA compared with the para-carcinoma tissues. 
Table III. Association between the expression level of Bmi-1 or PADI4 and clinicopathological variables.

\begin{tabular}{|c|c|c|c|c|c|c|c|c|c|c|}
\hline \multirow[b]{2}{*}{ Variable } & \multicolumn{5}{|c|}{ Bmi-1 } & \multicolumn{5}{|c|}{ PADI4 } \\
\hline & $\begin{array}{c}\text { Total } \\
\text { cases, } \mathrm{n}\end{array}$ & $\begin{array}{l}\text { Positive } \\
\text { cases, n }\end{array}$ & $\begin{array}{c}\text { Positive } \\
\text { rate, } \%\end{array}$ & $\chi^{2}$ & P-value & $\begin{array}{c}\text { Total } \\
\text { cases, } \mathrm{n}\end{array}$ & $\begin{array}{l}\text { Positive } \\
\text { cases, } \mathrm{n}\end{array}$ & $\begin{array}{c}\text { Positive } \\
\text { rate, } \%\end{array}$ & $\chi^{2}$ & P-value \\
\hline Gender & & & & 0.028 & 0.866 & & & & 2.600 & 0.107 \\
\hline Male & 61 & 45 & 73.8 & & & 61 & 45 & 73.8 & & \\
\hline Female & 25 & 18 & 72.0 & & & 25 & 14 & 56.0 & & \\
\hline Age, years & & & & 0.742 & 0.389 & & & & 0.711 & 0.399 \\
\hline$<60$ & 44 & 34 & 77.3 & & & 44 & 32 & 72.7 & & \\
\hline$\geq 60$ & 42 & 29 & 69.0 & & & 42 & 27 & 64.3 & & \\
\hline Differentiation degree & & & & 13.787 & 0.001 & & & & 4.773 & 0.092 \\
\hline High & 9 & 2 & 22.2 & & & 9 & 5 & 55.6 & & \\
\hline Moderate & 47 & 36 & 76.6 & & & 47 & 29 & 61.7 & & \\
\hline Poor & 30 & 25 & 83.3 & & & 30 & 25 & 83.3 & & \\
\hline Clinical stage & & & & & 0.005 & & & & 5.771 & 0.016 \\
\hline $\mathrm{I} / \mathrm{II}$ & 70 & 47 & 67.1 & & & 70 & 44 & 62.9 & & \\
\hline III/IV & 16 & 16 & 100.0 & & & 16 & 15 & 93.8 & & \\
\hline T classification & & & & 0.618 & 0.432 & & & & 6.672 & 0.010 \\
\hline $\mathrm{T} 1 / 2$ & 28 & 19 & 67.9 & & & 28 & 14 & 50.0 & & \\
\hline $\mathrm{T} 3 / 4$ & 58 & 44 & 75.9 & & & 58 & 45 & 77.6 & & \\
\hline Lymph node metastases & & & & & 0.005 & & & & 5.771 & 0.016 \\
\hline Negative & 70 & 47 & 67.1 & & & 70 & 44 & 62.9 & & \\
\hline Positive & 16 & 16 & 100.0 & & & 16 & 15 & 93.8 & & \\
\hline
\end{tabular}

Bmi-1, B-cell-specific Moloney leukemia virus insert site 1; PADI4, peptidyl arginine deiminase IV.

Table IV. Frequencies of altered expression of Bmi-1 and PADI4 in the 26 esophageal cancer tissues.

\begin{tabular}{|c|c|c|c|c|c|c|}
\hline \multirow[b]{2}{*}{ Gene } & \multicolumn{2}{|c|}{ Decreased expression } & \multicolumn{2}{|c|}{ Normal expression } & \multicolumn{2}{|c|}{ Overexpression } \\
\hline & Frequency, n & Percentage, $\%$ & Frequency, $\mathrm{n}$ & Percentage, $\%$ & Frequency, n & Percentage, $\%$ \\
\hline Bmi-1 & 2 & 7.69 & 7 & 26.92 & 17 & 65.38 \\
\hline PADI4 & 4 & 15.38 & 8 & 30.77 & 14 & 53.8 \\
\hline
\end{tabular}

Bmi-1, B-cell-specific Moloney leukemia virus insert site 1; PADI4, peptidyl arginine deiminase IV.

Table V. Association between the expression of Bmi-1 and PADI4 in esophageal cancer.

\begin{tabular}{lc}
\hline Protein expression status & Cases, $\mathrm{n}$ \\
\hline $\mathrm{Bmi}^{+} 1^{+} / \mathrm{PAD} 14^{+}$ & 47 \\
$\mathrm{BMI}-1^{+} / \mathrm{PAD} 14^{-}$ & 16 \\
$\mathrm{BMI}-1^{-} / \mathrm{PAD} 14^{+}$ & 12 \\
$\mathrm{BMI}-1^{-} / \mathrm{PAD} 14^{-}$ & 11 \\
\hline There were significant positive correlations between Bmi-1 and \\
PADI4 (r=0.214, P=0.047; chi-square test) Bmi-1, B-cell-specific \\
Moloney leukemia virus insert site 1; PADI4, peptidyl arginine \\
deiminase IV.
\end{tabular}

Correlation between Bmi-1 expression and PADI4 expression in ESCC tissues. Correlation analysis was performed to test the correlation between the expression of Bmi-1 mRNA and PADI4 mRNA. Bmi-1 overexpression was positively associated with PADI4 expression $(\mathrm{r}=0.534 ; \mathrm{P}=0.005)$. In addition, according to the results of immunohistochemical studies, the correlation coefficients indicated that there were significant positive correlations between Bmi-1 and PADI4 genes $(\mathrm{r}=0.214 ; \mathrm{P}=0.047$; Table V).

\section{Discussion}

It is well known that ESCC, a common malignant disease, is prone to invade adjacent regions and metastasize to lymph nodes or distant organs. At the point of diagnosis, metastasis 
A
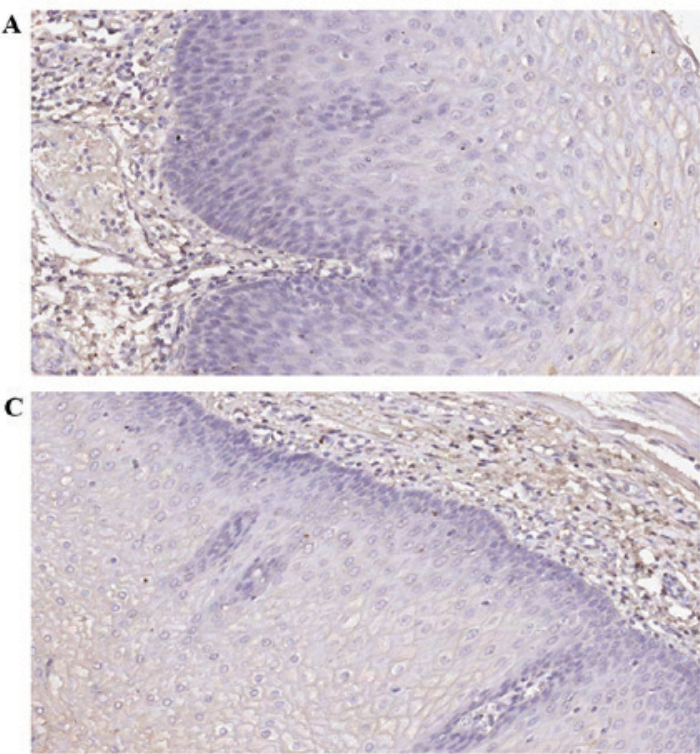

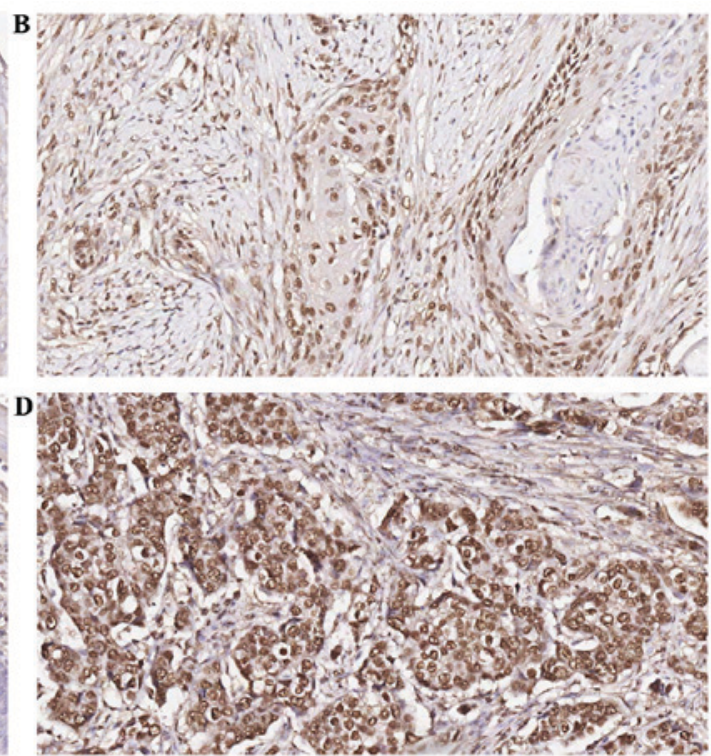

Figure 1. Immunohistochemical staining of ESCC using antibodies against Bmi-1 or PADI4. (A) Bmi-1 protein expression in adjacent non-cancerous tissues was negative; (B) Bmi-1 protein expression in ESCC cells was positive; (C) PADI4 protein expression in adjacent non-cancerous tissues was negative; (D) PADI4 protein expression in ESCC cells was positive. Original magnification, $\mathrm{x} 200$.
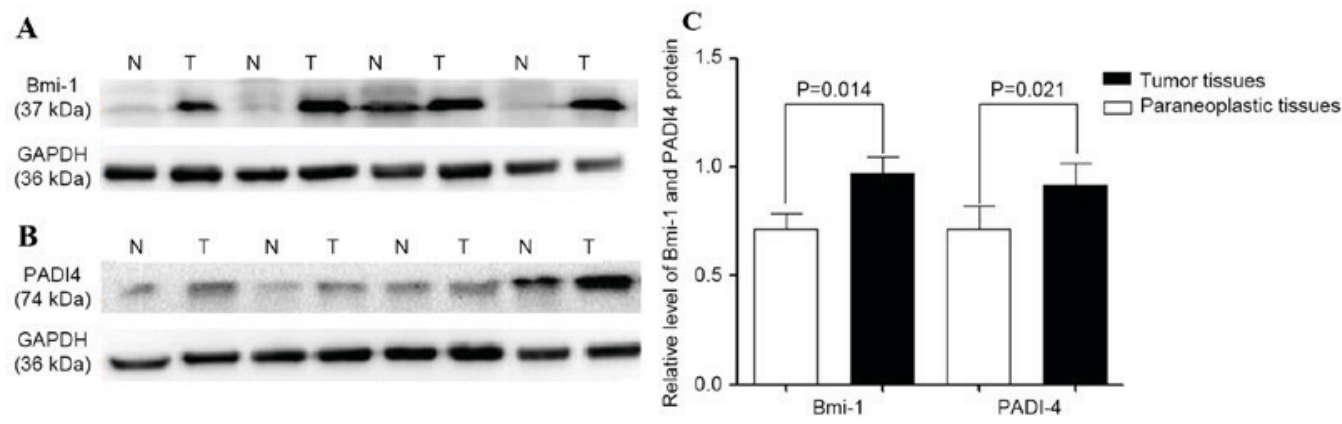

Figure 2. Overexpression of Bmi-1 and PADI4 in esophageal squamous cell carcinoma tumors. A total of 8 paired primary esophageal tumors and normal esophageal tissue from the same patient were determined for (A) Bmi-1 and (B) PADI4 expression at the protein level by western blot analysis. The expression level was normalized to GAPDH. (C) The expression levels of Bmi-1 and PADI4 were significantly increased in ESCC compared with para-carcinoma tissue samples. Bmi-1, B-cell specific Moloney leukemia virus insert site 1; PADI4, peptidyl arginine deiminase IV; T, primary esophageal tumors; N, normal esophageal tissue.

has already occurred in $>50 \%$ of patients with ESCC, with no chance of resection (23), which largely explains the poor prognosis of ESCC (5). Therefore, diagnostic markers of early ESCC may be useful to improve prognosis, and for selecting treatments properly. The purpose of the present study was to investigate the expression and clinicopathological roles of Bmi-1 and PADI4 in ESCC.

Mammalian polycomb group ( $\mathrm{PcG}$ ) protein complexes are generally classified as polycomb repressive complexes 1 or 2 (PRC1 or PRC2). Alterations in PcG expression have been observed in human tumors $(24,25)$. Bmi-1, a PRC1 that regulates proliferation and senescence in mammalian cells, plays an important role in the self-renewal of stem cells. Overexpression of Bmi-1 has been observed in several human cancers and its overexpression is often associated with poor prognosis in gastric cancer, bladder cancer and esophageal squamous cell carcinoma (2,24-26). It was reported that Bmi-1, as a proto-oncogene, plays an important role in the invasion and metastasis of neoplasms. Overexpression of Bmi-1 in esophageal cancer has been reported (25). The depth of invasion, clinical stage, lymph node metastasis status and lower survival rate have all been identified as associated with Bmi-1 overexpression $(2,25)$. In the present study, it was revealed that Bmi-1 plays an important role in ESCC progression. It was demonstrated that Bmi-1 expression is significantly upregulated $(\mathrm{P}<0.05)$ in ESCC tissues compared with adjacent noncancerous tissues. In addition, it was observed that positive expression of Bmi-1 is associated with clinical stage, differentiation degree and lymph node metastasis ( $\mathrm{N}$ classification), and the difference was statistically significant $(\mathrm{P}<0.05)$. This indicated that Bmi-1 protein may perform a crucial role in the carcinogenesis, progression and metastasis of ESCC.

Genome-wide analysis has demonstrated that PADI4 functions as an activator of gene expression by citrullination of transcription factors (27). Previous studies demonstrated that PADI4 is part of a transcriptional network that regulates pluripotency (28-31). It has been suggested that PADI4 may target different histone arginines $(32,33)$. Kolodziej et al 

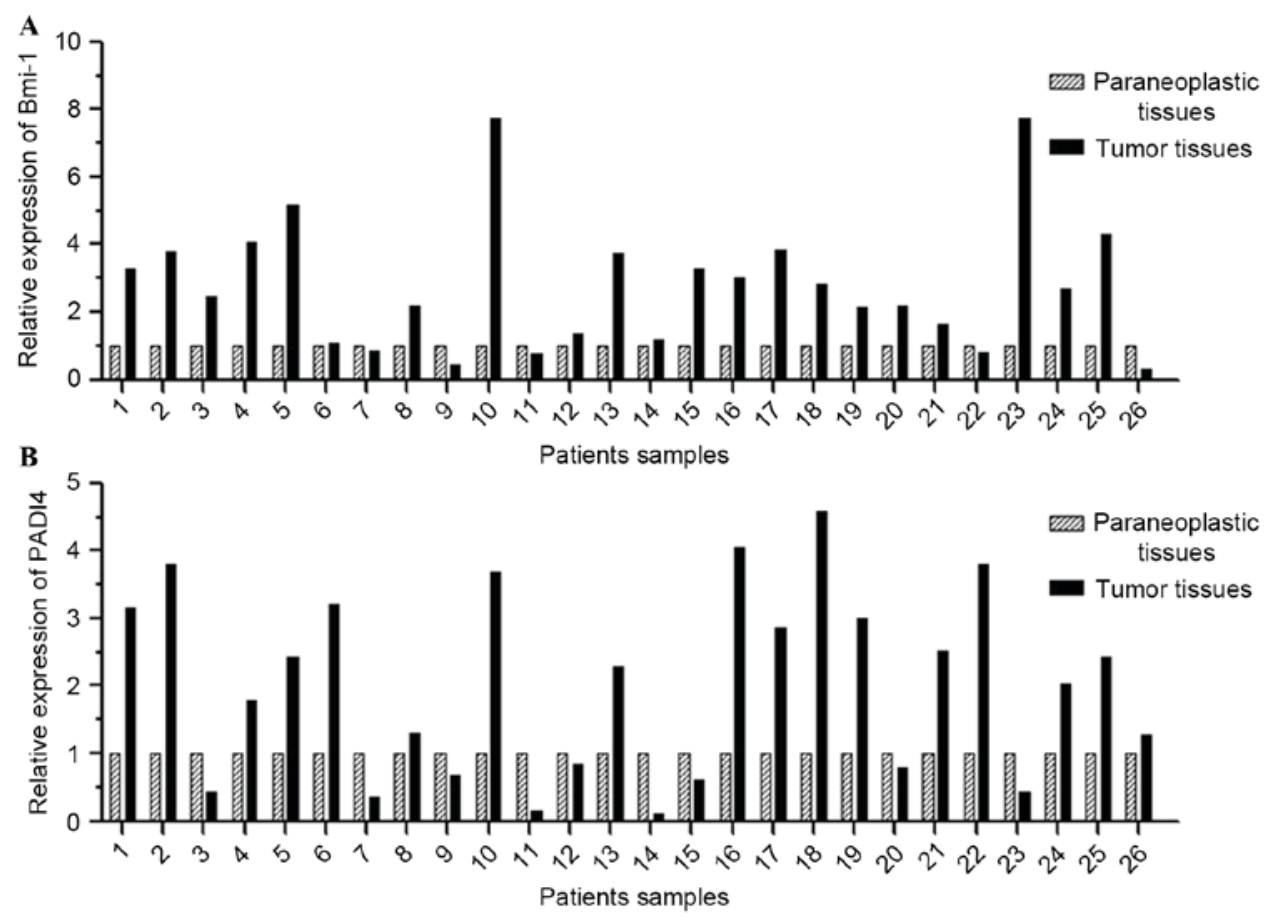

Figure 3. Bmi-1 and PADI4 expression is upregulated in ESCC. Analysis of (A) Bmi-1 mRNA and (B) PADI4 expression using reverse transcription-quantitative polymerase chain reaction in primary ESCC tumor tissue relative to matched noncancerous mucosal tissue, following normalization to $\beta$-actin $\mathrm{mRNA}$. A fold change of $\leq 0.5$ means downregulation and a fold change of $>2.0$ means upregulation. Bmi-1, B-cell specific Moloney leukemia virus insert site 1; PADI4, peptidyl arginine deiminase IV; ESCC, esophageal squamous cell carcinoma.

previously identified PADI4 as a novel interaction partner of T-cell acute lymphocytic leukemia protein 1 (Tal1), which is a critical regulator of hematopoietic gene expression and may act as an oncogene if aberrantly expressed, and identified a large number of genes that are co-regulated by PADI4 and Tal1 (31). Overexpression of PADI4 is often observed in growth of tumors, and the inhibitor $\mathrm{Cl}$-amidine reduces growth of a subset of cell lines (34). Chang et al confirmed that the expression level of PADI4 was positively associated with the pathological classification of ESCC. The previous study also identified that apoptosis corresponded to the expression of PADI4 in cultured EC cells that were treated with dichloroacetate (35). In the present study, the expression of PADI4 was significantly increased in ESCC tissues compared with the corresponding noncancerous mucosal tissues. In addition, it was also observed that positive expression of PADI4 was correlated with the depth of cancer invasion (T classification), clinical stage and lymph node metastasis ( $\mathrm{N}$ classification), with statistically significant differences $(\mathrm{P}<0.05)$. This indicated that PADI4 protein is associated with esophageal carcinogenesis, progression and metastasis, and that PADI4 may play a crucial role in ESCC.

The present study demonstrated that Bmi-1 and PADI4 are expressed abnormally in ESCC. The expression levels of Bmi-1 and PADI4 are associated with the carcinogenesis and progression of human tumors. However, the expression of Bmi-1 is not associated with depth of invasion $(\mathrm{P}>0.05)$. No association was observed between PADI4 expression and differentiation degree $(\mathrm{P}>0.05)$. These results may be due to the small size of patient cohort, and additional studies using larger samples are required to extend the present findings. The present study also identified a positive correlation between
Bmi-1 and PADI4 expression at mRNA $(\mathrm{r}=0.534 ; \mathrm{P}=0.005)$ and protein levels $(\mathrm{r}=0.214 ; \mathrm{P}=0.047)$. However, it remains unknown how Bmi-1 interaction with PADI4 affects carcinogenesis, progression and metastasis in ESCC.

The p14ARF-MDM2-p53 pathway, commonly referred to as the p53 pathway, is an important pathway in the development and progression of numerous human malignancies (36). The p53 pathway is usually inactivated by TP53 mutation, amplification of MDM2 or p14ARF deletion in a number of human cancers $(37,38)$. Previous studies have demonstrated that Bmi-1 is a potent repressor of the p14ARF-MDM2-p53 pathway $(13,39,40)$. Inactivation of the $\mathrm{p} 53$ pathway by Bmi-1 has been identified in lymphomagenesis and oncogenesis in human non-small cell lung cancer $(15,37,41)$. Yao et al reported that there is an inverse correlation between the expression of Bmi-1 and p14ARF, and thereby dysfunction of the p53 growth regulatory pathway during the development of gastric cardia adenocarcinoma (42). In addition, a number of studies proposed that PADI4 plays an important role in various cellular processes, including proliferation, the cell cycle and apoptosis (27,30-33). PADI4 overexpression has also been considered to reduce the expression of p53-targeted genes, resulting in the disruption of cellular apoptosis and of the normal cell cycle $(35,43,44)$. Previous studies have confirmed that PADI4 disrupts the apoptotic process via citrullination of histone $\mathrm{H} 3$, which acts on the promoter of p53 target genes $(44,45)$. Cui et al hypothesized that PADI4 may regulate migration, invasion and apoptosis in A2780 cells with wild-type p53 and in p53-null SKOV3 cells, and that PADI4 may be associated with the p53 gene (29). Apoptosis PCR array analysis demonstrated that PADI4 overexpression induced the decreased expression of the Fas ligand gene, 
which is one of the important genes downstream of p53. Additional studies proposed that TNF receptor superfamily member (TNFRSF) 9, Bcl-2 like protein 2, TNFRSF11B and Bcl-2 antagonist/killer 1 may perform important roles in the mechanism of action of PADI4, which is associated with ovarian tumorigenesis (29). The mechanism may be associated with the p53 gene $(46,47)$.

According to the present results, it was speculated that Bmi-1 and PADI4 may be involved in the associated signaling molecules of the p53 pathway, which mediate the regulation of esophageal cancer. It was hypothesized that overexpression of Bmi-1 may inhibit the activation of p14ARF and the function of the p53 pathway. It leads to tumor formation by regulating the expression of PADI4. Bmi-1, which is associated with PADI4 by the p14ARF-MDM2-p53 pathway, positively regulated the carcinogenesis and progression of ESCC.

To the best of our knowledge, this is the first study to investigate the association between Bmi-1 and PADI4 expression in ESCC. The expression of Bmi-1 and PADI4 was associated with esophageal cancer progression. The advanced stages of ESCC are more likely to express increased levels of Bmi-1 and PADI4. The present study detected that the associated gene expression and the mechanism may be associated with p53; however, the detailed mechanisms and how they are regulated in esophageal cancers were not investigated.

In conclusion, the present study demonstrated that the expression of Bmi-1 and PADI4 was associated with the carcinogenesis and progression of ESCC. Therefore, Bmi-1 and PADI4 may be used as prognostic markers in ESCC. In addition, a positive association was observed between Bmi-1 and PADI4, and this mechanism may be associated with the p53 pathway.

\section{Acknowledgements}

The authors thank the Medical Research Center of Qianfoshan Hospital of Shandong University for their excellent technical assistance. The present study was supported by the Ministry of Science and Technology Research Foundation (grant no. 2013GSF11836).

\section{References}

1. Zhang J, Zhu Z, Liu Y, Jin X, Xu Z, Yu Q and Li K: Diagnostic value of multiple tumor markers for patients with esophageal carcinoma. PLoS One 10: e0116951, 2015.

2. Zhang Y, Zhang YL, Chen HM, Pu HW, Ma WJ, Li XM, Ma H and Chen X: Expression of Bmi-1 and PAI-1 in esophageal squamous cell carcinoma. World J Gastroenterol 20: 5533-5539, 2014

3. Crew KD and Neugut AI: Epidemiology of upper gastrointestinal malignancies. Semin Oncol 31: 450-464, 2004.

4. Vaupel P and Mayer A: Hypoxia in cancer: Significance and impact on clinical outcome. Cancer Metastasis Rev 26: 225-239, 2007.

5. Sudo T, Iwaya T, Nishida N, Sawada G, Takahashi Y, Ishibashi M, Shibata K, Fujita H, Shirouzu K, Mori M and Mimori K: Expression of mesenchymal markers vimentin and fibronectin: The clinical significance in esophageal squamous cell carcinoma Ann Surg Oncol 20 (Suppl 3): S324-S335, 2013.

6. Song LB, Zeng MS, Liao WT, Zhang L, Mo HY, Liu WL, Shao JY, Wu QL, Li MZ, Xia YF, et al: Bmi-1 is a novel molecular marker of nasopharyngeal carcinoma progression and immortalizes primary human nasopharyngeal epithelial cells. Cancer Res 66 6225-6232, 2006.
7. van der Lugt NM, Domen J, Linders K, van Roon M, Robanus-Maandag E, te Riele H, van der Valk M, Deschamps J, Sofroniew M, van Lohuizen M, et al: Posterior transformation, neurological abnormalities, and severe hematopoietic defects in mice with a targeted deletion of the bmi-1 proto-oncogene. Genes Dev 8: 757-769, 1994.

8. Jacobs JJ, Kieboom K, Marino S, DePinho RA and van Lohuizen M: The oncogene and Polycomb-group gene bmi-1 regulates cell proliferation and senescence through the ink4a locus. Nature 397: 164-168, 1999.

9. Lu YW, Li J and Guo WJ: Expression and clinicopathological significance of Mel-18 and Bmi-1 mRNA in gastric carcinoma. J Exp Clin Cancer Res 29: 143, 2010.

10. Guo BH, Feng Y, Zhang R, Xu LH, Li MZ, Kung HF, Song LB and Zeng MS: Bmi-1 promotes invasion and metastasis, and its elevated expression is correlated with an advanced stage of breast cancer. Mol Cancer 10: 10, 2011.

11. Tao J, Liu YL, Zhang G, Ma YY, Cui BB and Yang YM: Expression and clinicopathological significance of Mel-18 mRNA in colorectal cancer. Tumour Biol 35: 9619-9625, 2014.

12. Dalley AJ, Pitty LP, Major AG, Abdulmajeed AA and Farah CS: Expression of ABCG2 and Bmi-1 in oral potentially malignant lesions and oral squamous cell carcinoma. Cancer Med 3: 273-283, 2014.

13. Li DW, Tang HM, Fan JW, Yan DW, Zhou CZ, Li SX, Wang XL and Peng ZH: Expression level of Bmi-1 oncoprotein is associated with progression and prognosis in colon cancer. J Cancer Res Clin Oncol 136: 997-1006, 2010

14. Guo P, Gao A, Zhang G, Han H and Zhou Q: Decoding the knots of initiation of oncogenic epithelial-mesenchymal transition in tumor progression. Curr Cancer Drug Targets 13: 996-1011, 2013.

15. Vonlanthen S, Heighway J, Altermatt HJ, Gugger M, Kappeler A, Borner MM, van Lohuizen M and Betticher DC: The bmi-1 oncoprotein is differentially expressed in non-small cell lung cancer and correlates with INK4A-ARF locus expression. Br J Cancer 84: 1372-1376, 2001.

16. Hagiwara T, Nakashima K, Hirano H, Senshu T and Yamada M: Deimination of arginine residues in nucleophosmin/B23 and histones in HL-60 granulocytes. Biochem Biophys Res Commun 290: 979-983, 2002.

17. Chang $X$ and Han J: Expression of peptidylarginine deiminase type 4 (PAD4) in various tumors. Mol Carcinog 45: 183-196, 2006.

18. Nakashima K, Arai S, Suzuki A, Nariai Y, Urano T, Nakayama M, Ohara O, Yamamura K, Yamamoto K and Miyazaki T: PAD4 regulates proliferation of multipotent haematopoietic cells by controlling c-myc expression. Nat Commun 4: 1836, 2013.

19. Chang X, Han J, Pang L, Zhao Y, Yang Y and Shen Z: Increased PADI4 expression in blood and tissues of patients with malignant tumors. BMC Cancer 9: 40, 2009.

20. Tanikawa C, Espinosa M, Suzuki A, Masuda K, Yamamoto K, Tsuchiya E, Ueda K, Daigo Y, Nakamura Y and Matsuda K: Regulation of histone modification and chromatin structure by the p53-PADI4 pathway. Nat Commun 3: 676, 2012.

21. Remmele W and Stegner HE: Recommendation for uniform definition of an immunoreactive score (IRS) for immunohistochemical estrogen receptor detection (ERICA) in breast cancer tissue. Pathologe 8: 138-140, 1987 (In German).

22. Livak KJ and Schmittgen TD: Analysis of relative gene expression data using real-time quantitative PCR and the 2(-Delta Delta C(T)) Method. Methods 25: 402-408, 2001.

23. Enzinger PC and Mayer RJ: Esophageal cancer. N Engl J Med 349: 2241-2252, 2003.

24. Zhang XW, Sheng YP, Li Q, Qin W, Lu YW, Cheng YF, Liu BY, Zhang FC, Li J, Dimri GP and Guo WJ: BMI1 and Mel-18 oppositely regulate carcinogenesis and progression of gastric cancer. Mol Cancer 9: 40, 2010.

25. Liu WL, Guo XZ, Zhang LJ, Wang JY, Zhang G, Guan S, Chen YM, Kong QL, Xu LH, Li MZ, et al: Prognostic relevance of Bmi-1 expression and autoantibodies in esophageal squamous cell carcinoma. BMC Cancer 10: 467, 2010.

26. Qin ZK, Yang JA, Ye YL, Zhang X, Xu LH, Zhou FJ, Han H, Liu ZW, Song LB and Zeng MS: Expression of Bmi-1 is a prognostic marker in bladder cancer. BMC Cancer 9: 61, 2009.

27. Zhang X, Gamble MJ, Stadler S, Cherrington BD, Causey CP, Thompson PR, Roberson MS, Kraus WL and Coonrod SA: Genome-wide analysis reveals PADI4 cooperates with Elk-1 to activate c-Fos expression in breast cancer cells. PLoS Genet 7: e1002112, 2011. 
28. Christophorou MA, Castelo-Branco G, Halley-Stott RP, Oliveira CS, Loos R, Radzisheuskaya A, Mowen KA, Bertone P, Silva JC, Zernicka-Goetz M, et al: Citrullination regulates pluripotency and histone H1 binding to chromatin. Nature 507: 104-108, 2014

29. Cui YY, Yan L, Zhou J, Zhao S, Zheng YB, Sun BH, Lv HT, Rong FN and Chang XT: The role of peptidylarginine deiminase 4 in ovarian cancer cell tumorigenesis and invasion. Tumour Biol 37: 5375-5383, 2016.

30. Tanikawa C, Espinosa M, Suzuki A, Masuda K, Yamamoto K, Tsuchiya E, Ueda K, Daigo Y, Nakamura Y and Matsuda K: Regulation of histone modification and chromatin structure by the p53-PADI4 pathway. Nat Commun 3: 676, 2012.

31. Kolodziej S, Kuvardina ON, Oellerich T, Herglotz J, Backert I, Kohrs N, Buscató El, Wittmann SK, Salinas-Riester G, Bonig H, et al: PADI4 acts as a coactivator of Tall by counteracting repressive histone arginine methylation. Nat Commun 5: 3995, 2014

32. Cuthbert GL, Daujat S, Snowden AW, Erdjument-Bromage H, Hagiwara T, Yamada M, Schneider R, Gregory PD, Tempst P, Bannister AJ and Kouzarides T: Histone deimination antagonizes arginine methylation. Cell 118: 545-553, 2004.

33. Wang Y, Wysocka J, Sayegh J, Lee YH, Perlin JR, Leonelli L, Sonbuchner LS, McDonald CH, Cook RG, Dou Y, et al: Human PAD4 regulates histone arginine methylation levels via demethylimination. Science 306: 279-283, 2004.

34. Slack JL, Causey CP and Thompson PR: Protein arginine deiminase 4: A target for an epigenetic cancer therapy. Cell Mol Life Sci 68: 709-720, 2011

35. Chang X, Hou X, Pan J, Fang K, Wang L and Han J: Investigating the pathogenic role of PADI4 in oesophageal cancer. Int J Biol Sci 7: 769-781, 2011.

36. Hashiguchi Y, Tsuda $\mathrm{H}$, Yamamoto $\mathrm{K}$, Inoue $\mathrm{T}$, Ishiko $\mathrm{O}$ and Ogita S: Combined analysis of $\mathrm{p} 53$ and RB pathways in epithelial ovarian cancer. HUM Pathol 32: 988-996, 2001.

37. Lindström MS, Klangby U and Wiman KG: p14ARF homozygous deletion or MDM2 overexpression in Burkitt lymphoma lines carrying wild type p53. Oncogene 20: 2171-2177, 2001.

38. Ichimura K, Bolin MB, Goike HM, Schmidt EE, Moshref A and Collins VP: Deregulation of the p14ARF/Mdm2/p53 pathways is a prerequisite for human astrocytic gliomas with G1-S transition control gene abnormalities. Cancer Res 60: 417-424, 2000.
39. Shafaroudi AM, Mowla SJ, Ziaee SA, Bahrami AR, Atlasi Y and Malakootian M: Overexpression of BMI1, a polycomb group repressor protein, in bladder tumors: A preliminary report. Urol J 5: 99-105, 2008.

40. Taran K, Wysocka A, Sitkiewicz A, Kobos J and Andrzejewska E: Evaluation of potential prognostic value of Bmi-1 gene product and selected markers of proliferation (Ki-67) and apoptosis (p53) in the neuroblastoma group of tumors. Postepy Hig Med Dosw (Online) 70: 110-116, 2016.

41. Beà S, Tort F, Pinyol M, Puig X, Hernández L, Hernández S, Fernandez PL, van Lohuizen M, Colomer D and Campo E: BMI-1 gene amplification and overexpression in hematological malignancies occur mainly in mantle cell lymphomas. Cancer Res 61: 2409-2412, 2001.

42. Yao D, Wang Y, Xue L, Wang H, Zhang J and Zhang X: Different expression pattern and significance of p14ARF-Mdm2-p53 pathway and Bmi-1 exist between gastric cardia and distal gastric adenocarcinoma. Hum Pathol 44: 844-851, 2013

43. Tanikawa C, Ueda K, Nakagawa H, Yoshida N, Nakamura Y and Matsuda K: Regulation of protein Citrullination through p53/PADI4 network in DNA damage response. Cancer Res 69: 8761-8769, 2009.

44. Li P, Yao H, Zhang Z, Li M, Luo Y, Thompson PR, Gilmour DS and Wang Y: Regulation of p53 target gene expression by peptidylarginine deiminase 4. Mol Cell Biol 28: 4745-4758, 2008.

45. Yao H, Li P, Venters BJ, Zheng S, Thompson PR, Pugh BF and Wang Y: Histone Arg modifications and p53 regulate the expression of OKL38, a mediator of apoptosis. J Biol Chem 283: 20060-20068, 2008

46. Braga Lda C, Silva LM, Piedade JB, Traiman P and da Silva Filho AL: Epigenetic and expression analysis of TRAIL-R2 and BCL2: On the TRAIL to knowledge of apoptosis in ovarian tumors. Arch Gynecol Obstet 289: 1061-1069, 2014.

47. Kraljevic Pavelic S, Cacev T and Kralj M: A dual role of p21waf1/ cip1 gene in apoptosis of HEp-2 treated with cisplatin or methotrexate. Cancer Gene Ther 15: 576-590, 2008. 